Tinjauan Pustaka

\title{
Infeksi Cacing dan Alergi
}

\author{
Selfi Renita Rusjdi
}

\begin{abstract}
Abstrak
Infeksi cacing masih merupakan masalah kesehatan di Indonesia dan negara berkembang lainnya. Penyakit ini sering terjadi di daerah dengan higienisitas dan sanitasi yang masih kurang. Respon imun tubuh host terhadap cacing ini mirip dengan respon tubuh terhadap penyakit alergi. Respon pada penyakit kecacingan dan alergi ini merupakan respon Thelper2 yaitu diferensiasi dan polariasasi sel limfosit $T$ lebih dominan pada Th2. Pada kenyataannya, ditinjau dari segi epidemiologi, penyakit kecacingan dan penyakit alergi terdapat pada daerah yang sangat berbeda. Prevalensi penyakit alergi cenderung lebih banyak terjadi di daerah maju dengan higiene dan sanitasi yang baik. Keadaan ini menimbulkan pertanyaan apakah kecacingan mempunyai efek proteksi terhadap manifestasi klinis berbagai macam penyakit alergi. Hygiene hypothesis merupakan teori yang relevan dalam menjawab pertanyaan ini. Mekanisme yang dapat menerangkan fenomena ada adalah saturasi sel mast, penghambatan oleh IgG4 dan modified Th2 response.
\end{abstract}

Kata kunci: infeksi cacing, alergi, respon Th2

\begin{abstract}
Helminthiasis is still unsolved problem in Indonesia and other developing countries. This disease is frequently occurred in poor personal hygiene and environmental sanitation. The human immune response to helminth infections is similar with response to allergic disease. These disease present $T$ helper2 (Th2) response which characterized dominant differentiation and proliferation of Th2. In fact, epidemiology study shows that they are occurred in different type of region. High prevalence of allergic disease is found in modern country which is well established sanitation and good personal hygiene. This condition raises fundamental question whether helminthiasis is associated with protection against allergic disease. Hygiene hypothesis is a theory that can explain this phenomen. The mechanisms are mast cell saturation, IgG4 blocking and modified Th2.
\end{abstract}

Keywords: helminthiasis, allergy, Th2 response

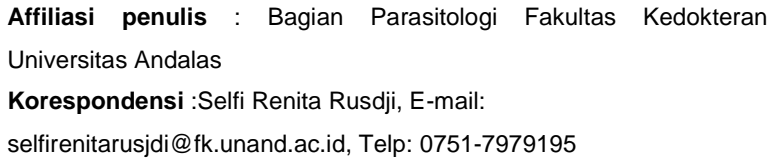

Affiliasi penulis : Bagian Parasitologi Fakultas Kedokteran Universitas Andalas

Korespondensi :Selfi Renita Rusdji, E-mail:

selfirenitarusjdi@fk.unand.ac.id, Telp: 0751-7979195

\section{PENDAHULUAN}

Kecacingan masih merupakan masalah kesehatan di Indonesia dan negara berkembang. Penyakit ini sering terjadi di daerah dengan ketersediaan air bersih dan sanitasi yang tidak memadai. Sistem imun tubuh host dalam merespon infeksi cacing ini sama dengan respon imun terhadap penyakit alergi yaitu respon Th2 yang ditandai dengan peningkatan kadar interleukin-4 (IL-4), IL-5, IL-13 dan disertai dengan peningkatan kadar imunoglobulin $\mathrm{E}$
( $\lg E)$ dan eosinofilia. Walaupun kedua penyakit tersebut mempunyai fenomena imunologi yang sama, ternyata kedua penyakit ini terjadi pada daerah dengan yang sang at berbeda. Penyakit alergi lebih sering terjadi di negara maju dengan higienisitas dan sanitasi yang baik. Keadaan ini menimbulkan dugaan bahwa infeksi cacing dapat melindungi individu terhadap munculnya alergi. ${ }^{1,2}$

\section{Hygiene Hypothesis}

Hygiene hypothesis merupakan suatu hipotesis yang menyatakan bahwa kurangnya paparan tubuh terhadap agen infeksius di masa kanak - kanak akan menyebabkan sistem imun tidak mampu untuk 
berkembang secara sempurna sehingga akan menimbulkan reaksi yang tidak sesuai denga yang seharusnya. Paparan terhadap agen infeksi ini sangat mempengaruhi keseimbangan Th1 dan Th2 pada respon imun tubuh. ${ }^{3,4}$

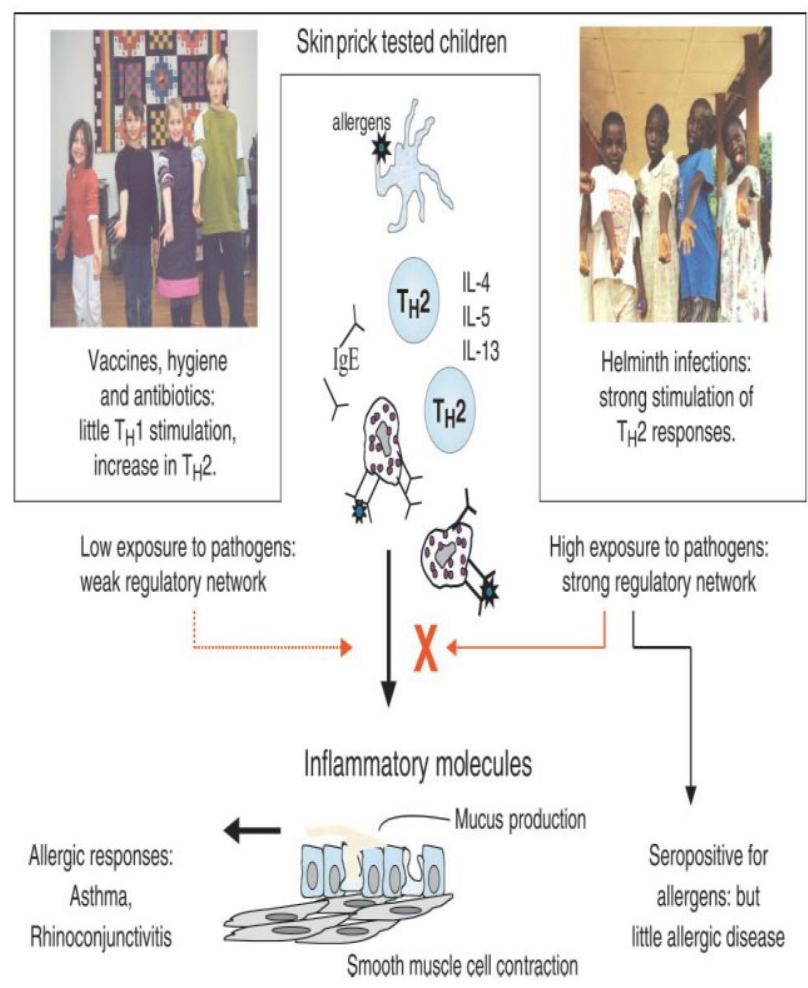

Gambar 1. Hygiene hypothsesis - helminth ${ }^{3}$

Hygiene hypothsesis - helminth

Higienisitas yang bagus, penggunaan vaksin dan antibiotik yang sering akan mengakibatkan tubuh kurang paparan terhadap agen penyebab infeksi seperti bakteri dan virus. Keadaan ini mengakibatkan respon imun tubuh oleh sel Th1 kurang teraktivasi dan mengarah ke Th2 yang ditandai dengan peningkatan imunoglobulin $\mathrm{E}$ ( $\mathrm{lgE}$ ) terhadap alergen, mastositosis dan eosinofilia. Proses ini akan mengakibatkan reaksi inflamasi yang muncul berupa peningkatan produksi mukus, peningkatan kontraksi otot polos memicu reaksi alergi pada saliran pernapasan.,

Pada negara berkembang, paparan terhadap agen infeksi sering terjadi dan berlangsung kronik.Keadaan ini mengakibatkan sel Th1 sering teraktivasi dan respon imun tubuh tidak mengarah ke Th2 yang merupakan dasar terjadinya penyakit alergi.Khusus pada infeksi cacing, terjadi pengecualian. Sama halnya dengan penyakit alergi, penyakit kecacingan menimbulkan respon yang mengarah ke Th2. Walaupun respon yang timbul sama dengan respon imun terhadap alergen, infeksi cacing ternyata dapat memproteksi individu dari penyakit alergi. Ternyata fenomena ini terjadi karena adanya aktifitas regulatory network yang dapat menekan reaksi alergi. Aktifitas regulatory network ini akan terjadi pada infeksi cacing kronik. $^{3}$

\section{Infeksi cacing}

Penyakit kecacingan yang terjadi di Indonesia sering disebabkan oleh cacing yang tergolong ke dalam soil transmitted helminth. Yang termasuk ke dalam soil transmitted helminth adalah Ascaris lumbricoides (cacing gelang), Ancylostoma duodenale dan Necator americanus (cacing tambang), Trichuris trichiura (cacing cambuk). Spesies cacing yang juga sering menginfeksi populasi Indonesia adalah Oxyuris vermicularis. Cacing ini tidak tergolong soil transmitted helminth karena tidak memerlukan tanah untuk tumbuh menjadi stadium yang dapat menginfeksi manusia. Cacing jaringan yang sering menjadi penyebab infeksi di Indonesia adalah Wuchereria bancrofti, Brugia malayi dan Brugia timori. ${ }^{1,5}$

Terdapat beberapa keadaan yang dapat mempengaruhi munculan penyakit alergi pada penderita kecacingan antara lain waktu dan lamanya terjadi infeksi cacing, intensitas infeksi, genetik dan jenis cacing. ${ }^{1}$

1. Waktu dan lamanya terjadi infeksi cacing.

Individu yang terpapar oleh cacing dapat mengalami reaksi alergi terhadap antigen somaik ataupun produk yang dihasilkan oleh cacing tersebut. Keadaan ini biasanya terjadi para orang yang kurang terpapar oleh antigen cacing pada masa lalunya seperti imigran, turis atau pendatang dari daerah dengan karakteristik yang berbeda. ${ }^{6,7}$ Salah satu contoh yang menggambarkan keadaan ini adalah Sindroma Loeffler yang diakibatkan oleh larva Ascaris lumbricoides yang bermigrasi ke paru. Pada kelompok yang jarang terpapar ini juga menunjukkan gejala reaksi alergi yang lebih kuat terhadap alergen lain. Penekanan atau proteksi terhadap penyakit alergi terjadi pada kelompok populasi di daerah endemis di mana infeksi cacing cenderung berlangsung kronis sesuai dengan lamanya waktu yang dibutuhkan oleh cacing untuk mencapai organ target, tumbuh dewasa dan berkembang biak. ${ }^{1,8}$ Beberapa penelitian terakhir, 
diketahui bahwa ibu hamil yang terinfeksi cacing akan mempengaruhi imunitas bayi yang dilahirkannya. ${ }^{9,10}$

\section{Intensitas infeksi}

Infeksi cacing dengan intensitas yang berat lebih bersifat proteksi dalam menekan reaksi alergi dibandingkan dengan infeksi intensitas ringan.Keadaan ini lebih jelas terlihat efeknya pada cacing yang hidup di jaringan dibandingkan dengan cacing usus.Infeksi cacing dengan intensitas ringan bahkan dapat meningkatkan reaksi penyakit alergi. Penelitian yang dilakukan di Venezuela, Gambia, Ethiopia, Taiwan dan Ecuador memperlihatkan bahwa populasi yang terinfeksi cacing usus Ascaris lumbricoides, cacing tambang dan Trichuris trichiura terlindungi dari reaksi alergi. Hasil yang sama juga terlihat pada populasi yang menderita infeksi cacing schistosoma dan filaria yang berada di Gabon, Brazil dan Indonesia. Pada populasi yang menderita infeksi dengan intensitas ringan menunjukkan potensi untuk mengalami penyakit alergi. Pendatang yang berasal dari daerah non endemis ke daerah endemis penyakit schistosmiasis cenderung mengalami gejala akut berupa demam, eosinofilia dan gejala gangguan paru berupa batuk dan kesulitan bernafas. ${ }^{1,11}$

\section{Genetik individu yang terinfeksi}

Individu dengan genetik tertentu mempunyai kerentanan lebih tinggi untuk mengalami alergi baik terhadap cacing maupun alergen lain. Sebagai contoh, penduduk Afrika yang berada di daerah pedalaman lebih sedikit mengalami alergi. Kejadian sebaliknya terjadi pada populasi keturunan asli Afrika yang tinggal di negara maju cenderung memperlihatkan prevalensi dan gejala alergi yang lebih berat dibandingkan dengan penduduk pribumi negara maju tersebut. ${ }^{12}$

\section{Jenis cacing}

Cacing yang berbeda akan memberikan efek dan resiko yang berbeda pula terhadap munculan penyakit alergi. Beberapa penelitian menunjukkan bahwa pada penderita infeksi Ascaris lumbricoides memperlihatkan peningkatan kejadian asma.Hasil ini berbeda dengan penelitian terhadap infeksi akut cacing Toxocara spp pada manusia. Infeksi Toxocara pada hospes selain hospes definitifnya cenderung menimbulkan gangguan atopi atau alergi yang berperan dalam proses perlawanan dan eliminasi cacing dari dalam tubuh. ${ }^{13}$
Hubungan kecacingan dengan alergi

Antigen cacing dapat merangsang respon inflamasi alergi terhadap antigen cacing itu sendiri. Respon inflamasi ini akan tertekan jika infeksi cacing berlangsung kronis. Beberapa penelitian epidemiologi menunjukkan bahwa pada penderita infeksi Soil Transmitted Helminth yang kronik mengalami pengurangan reaksi tes kulit terhadap alergen, mengurangi resiko terkena penyakit alergi berupa asma, rhinitis dan dermatitis atopik. ${ }^{1}$

Telah diketahui dari penelitian para ahli bahwa infeksi cacing usus menimbulkan perubahan keseimbangan Th1/Th2 ke arah sel Th2 (Th2 polarized). ${ }^{14,15}$ Polarisasi Th2 yang terjadi pada infeksi cacing usus ini sama dengan polarisasi Th2 pada penyakit alergi. Kesamaan respon imun ini mempunyai klinis yang sangat berbeda. Beberapa penelitian (seperti di Kenya, Ethiopia, Ekuador dan Venezuela) telah dilakukan untuk mengetahui hubungan respon imun infeksi cacing terhadap alergi. Hasil penelitian menunjukkan bahwa rendahnya prevalensi alergi pada masyarakat di negara berkembang disebabkan efek proteksi dari infeksi cacing. $^{16}$

Terdapat beberapa mekanisme yang dapat menerangkan efek proteksi infeksi cacing terhadap alergi:

I. Saturasi sel mast

Imunoglobulin $\mathrm{E}$ berperan pada manifestasi reaksi alergi dan infeksi cacing. Pada infeksi cacing terjadi pembentukan IgE poliklonal. IgE poliklonal ini bersifat tidak spesifik akan menempel pada reseptor Fce sel mast sehingga penempelan IgE spesifik alergen pada sel mast terhambat dan tidak terjadi degranulasi histamin. Induksi lgE poliklonal ini juga dapat melindungi cacing dari serangan imunitas host sehingga memungkinkan cacing dapat hidup lama dan berkembang biak dengan aman dalam tubuh host tanpa menimbulkan gejala dan tanpa membahayakan cacing itu sendiri. ${ }^{3,17}$

II. Penghambatan oleh IgG4 (blocking lgG4)

Infeksi cacing akan memodulasi produksi lgG4. Antibodi IgG4 ini akan menghambat degranulasi sel efektor sehingga menekan reaksi alergi. Antibodi ini mampu menghambat $\lg \mathrm{E}$ untuk berikatan dengan alergen dengan cara menetralkan molekul alergen 
sebelum alergen tersebut berinteraksi dengan $\lg \mathrm{E}$ yang terikat pada reseptor sel mast danm basofil. ${ }^{3,18}$

III. Modified Th2

Pada infeksi cacing kronis cacing usus, terjadi respon "modified Th2" yang melibatkan peranan Treg (Tregulator). Sel Treg ini akan mengekspresikan interleukin 10 (IL-10) dan transforming growth factor $\beta$ (TGF- $\beta$ ). Kedua sitokin ini dapat menghambat imunitas seluler dan inflamasi alergi. ${ }^{18}$

\section{DAFTAR PUSTAKA}

1. Cooper PJ. Interactions between helminth parasites and allergy. Curr Opin Allergy Clin Immunol. 2009 February; 9(1): 29-37.

2. Girgis MN, Gundra MU, Loke P. Immune regulation during helminth infection. PLOS Pathogen. 2013; 9(4):1-3.

3. Yazdanbakhsh M, Kremsner GP, Ree VR Allergy, Parasites and the Hygiene Hypothesis. Science Compass. 2002; 296: 490-4.

4. Sitcharungsi, Raweerat; Sirivichayakul, Chukiat. Allergic diseases and helminth infections. Pathogens and Global Health. 2013;107(3):110-5.

5. Gandahusada S., Ilahude D. H., Pribadi W Parasitologi Kedokteran edisi ketiga. Fakultas Kedokteran Universitas Indonesia. 2004

6. Cooper PJ, Barreto ML, Rodrigues LC. Human allergy and geohelminth infections: a review of the literature and a proposed conceptual model to guide the investigation of possible causal associations. Br Med Bull. 2006;79-80:203-18.

7. Rodrigues LC, Newcombe PJ, Cunha SS, et al. Early infection with Trichuris trichiura and allergen skin test reactivity in later childhood. Clin Exp Allergy. 2008;38:1769-77.

8. Yazdanbakhsh M, Biggelaar A, Maizels RM. Th2 Responses without Atopy: Immunoregulation in Chronic Helminth Infection and Reduced Allergic Disease.
Trends in Immunology 2001; 22: 372-7.

9. Guadalupe I, Mitre E, Benitez S, et al. Evidence for in utero sensitization to Ascaris lumbricoides in newborns of mothers with ascariasis. J Infect Dis. 2009;199:1846-50.

10. Djuardi $Y$, Wibowo $H$, Supali $T$, et al. Determinants of the relationship between cytokine production in pregnant women and their infants. PLoS One. 2009;4:e7711.

11. Smits $\mathrm{HH}$, Yazdanbakhsh M. Chronic helminth infections modulate allergen-specific immune responses: protection against development of allergic disorders? Ann Med. 2007;39:428-39.

12. Obeng BB, Hartgers F, Boakye D, Yazdanbakhsh M. Out of Africa: what can be learned from the studies of allergic disorders in Africa and Africans? Curr Opin Allergy Clin Immunol. 2008;8:391-7.

13. Smits $\mathrm{HH}$, Everts $B$, Hartgers CF, Yazdanbakhsh M. Chronic Helminth Infections Protect Against Allergic Diseases by Active Regulatory Processes. Current Allergy and Asthma Reports. 6 January 2010.

14. Fallon PG, Mangan NE. Suppression of the Th2-type allergic reaction by helminth infection. Nature Review Immunology March 2007; 7: 220-30

15. Hartgers FC, Obeng BB, Boakye D, Yazdanbakhsh M. Immune Response during Helminth - Malaria Co-Infection: A Pilot Study in Ghanian School Children. Journal of Parasitology 2008; 135: 855-90.

16. Cooper PJ. Intestinal Worm and Human Allergy. Parasite Immunology. 2004; 16: 1-2

17. Zang P, Mutapi F, 2006. IgE: a Key Antibody in Schistosoa Infection. Electronic Journal of Biology, Vol. 2(1): 11-4.

18. Maizels RM, Yazdanbakhsh. Immune Regulation by Helminth Parasites. Cellular and Molecular Mechanism. Nature Review 2003;3:733-44. 